JOURNAL DE PHYSIQUE IV

Colloque C7, supplément au Journal de Physique III, Vol. 1, décembre 1991

C 7-221

\title{
CLINICAL APPLICATION OF UV EXCIMER LASERS
}

\author{
V.V. LANTUKH, M.M. PYATIN and A.M. RAZHEV \\ "Eye Microsurgery" R. \& T. Complex, Novosibirsk Affiliated Branch, 10 Kolkhidskaya St., \\ Novosibirsk 630071, USSR \\ Institute of Laser Physics, Siberian Branch of the USSR Academy of Sciences, 13/3 \\ Lavrentyev Pr., Novosibirsk 630090, USSR
}

\begin{abstract}
The problems of using UV excimer lasers generating at the 193,223 and $248 \mathrm{~nm}$ wavelengths in the treatment of myopia, aphakia, glaucoma and Herpes Simplex keratitis is discussed. The results of clinical application of these excimer lasers are presented.
\end{abstract}

The scope of laser surgery used in eye disorders is widening from year to year. Lately, the use of excimer lasers emitting UV radiation has been attracting great interest. To the well-known advantages of laser surgery (sterility and no-touch technique) another important feature is added - the ability to produce incisions of controlled:shape and depth with submicron precision and without any damage to the adjacent tissues. A number of workers proved it experimentally [1-5]. The mutagenic effect of UV laser - corneal tissues (bone marrow cells) interaction was studied. The number of possible laser-induced chromosome oberrations was shown to be not higher than that of spontaneous mutations [7].

The positive results obtained made it possible to use excimer lasers for the treatment of certain eye disorders.

Materials and methods.

A specially designed pulsed excimer laser with a short pulse scheme generating effectively at all transitions of rare gas halides with the energy of several dozen mu per pulse the duration of which is $4.5 \pm 0.5$ ns was used [8].

The laser is physically and optically coupled with the operating microscope by means of a delivery system making it possible to project a focal plane onto the cornea.

Treatment of Herpes Simplex keratitis.

122 patients with a severe or torpid form of the disease underwent laser treatment. In this group 110 patients had epithelial dendri form keratitis, 8 patients had epithelial ulcerative keratitis and 4 patients had deep stromal keratitis. Prior to laser treatment epibulbar anesthesia was used. The affected area of the cornea was determined by instillation of fluorescein. 
A helium neon laser was used to enable the surgeon to define the focal plane of the beam on the cornea. Photoablation of the corneal epithelium, necrotized tissues and infiltrated was carried out with the excimer laser. The operating microscope was used to control the depth and the area of the ablated zone. Low energies of radiation (0.4-0.5 mJ) were used. The KrF excimer laser generated at the wavelength of $248 \mathrm{~nm}$. During the exposure the diameter of the focal spot could be changed depending on the area of the lesion. No antiviral preparations were used postoperatively. The findings of the follow-up examination showed the $248 \mathrm{~nm}$ wavelength to be the most effective in the laser treatment of Herpes dendriform keratitis. In this group of patients recovery and epithelialization were observed by the 4 th postoperative day. If more than one third of the cornea was affected, epithelialization and recovery were noted by the $8 \mathrm{th}-10 \mathrm{th}$ day postoperatively. In patients with stromal keratitis the recovery process lasted 2-3 weeks. In all groups of patients there were no recurrences..

\section{Treatment of Refraction Errors.}

The excimer laser gives a unique possibility of changing the curvature of the anterior surface of the cornea and thereby changing its refractive power.

The study group consisted of 24 patients with myopic anisometropia and 2 patients with posttraumatic aphakia, synechial cicatrices and an! irregular pupil. To perform laser surgery in the latter cases a special rotating aperture was designed which produced a beam of energy distributed from the center towards the periphery. Thus, a positive meniscus of the cornea was formed. To obtain this result the curvature radius of the central cornea had to be $6 \mathrm{~mm}$. Following the healing of the ablated zone the second stage of the operation was performed - reconstruction of the iris and the vitreous.

To correct myopia of high degree a rotating mask was used to produce a beam with the maximum energy in the center to form a negative meniscus. Twenty patients had laser treatment without Bowman's membrane being separated. In 4 patients the superficial layer of the cornea was removed. The bed was $150 \mathrm{~m}$ deep, its area being $5 \mathrm{~mm}$. The depth of the ablated zone depth in the central cornea depended on the preoperative refraction and corneal thickness and was equal to $30-50 \mu \mathrm{m}$. In 4 patients the separated corneal flap was positioned in its original place and fixed with the biologic glue.

Analysing the clinical findings obtained one can say that the use of $193 \mathrm{~nm}$ radiation gives good visual results; there is practically no haze and the degree of astigmatism did not exceed the physiologic norm. With the use of $248 \mathrm{~nm}$ radiation the clinical outcomes were worse especially in the immediate post-operative period on account of the superficial haze of the bed floor. But in the follow-up period (more than 1 year) there were no signs of the haze. The most effective technique of preparing the cornea for laser treatment was a very thorough and careful removal of the superficial epithelium.

Treatment of open-angle glaucoma.

The excimer laser was used to treat 16 patients with open-angle glaucoma. The surgical technique was deep sclerectomy (perforating and nonperforating). After separating conjunctival and scleral flaps the zone of Schlemm's canal was opened and its outer wall lamellae were removed with the laser radiation in the form of a focal spot of $1 \mathrm{~mm}$ diametes, with the radiation energy of $5 \mathrm{~mJ}$ and energy density up to $800 \mathrm{~mJ} / \mathrm{cm}^{2}$. 
If filtration was established after this procedure, the operation was finished. In pronounced trabecular sclerosis laser ablation of the inner wall of the Schlemm's canal was used, and laser basal iridectomy was performed. The scleral and conjunctival flaps were sutured on. The findings of short-term and long-term follow-up showed stable normalization of intraocular pressure in all the patients. In one patient who had undergone non-perforating sclerectomy instillations of miotics were necessary.

Thus, the excimer Iaser can be considered a useful ophthalmic tool in the treatment of certain eye disorders. The $193 \mathrm{~nm}$ excimer laser is more effective in refractive corneal surgery, whereas the 248 laser proved to be useful in the laser treatment of Herpes simplex keratitis. Good clinical outcomes in patients with open-angle glaucoma depend on the type of the surgical technique used and on the laser output power.

1. Trokel S.L., Srinivasan R., Braren B. Excimer Laser Surgery of the Cornea // Amer. J. Ophthalmol. - 1983. - Vol. 96. - N 6. - P. 710715

2. Berlin M.S., Martinez M., Papaioannou T., Grundfest W., Goldenberg T., Laudenslager J. Goniophotoablation: Excimer Laser glaucoma filtering surgery // Lasers and Light in Ophthalmology. - 1988. - Vol. 2. - N 1. - P. 17-24.

3. Beiler T., Bende T., Wollensak J., Trokel S.E. Excimer Laser Keratectomy for Correction of Astigmatism // Amer. J. Ophthalmol. 1988. - Vol. 105. - N 2. - P. 117-124.

4. Aron-Rosa D.S., Borner C.F., Gross M., Timsit J.-C., Delacour M., Bath $P$.E. Wound healing following excimer laser radial Keratotomy// J. Cataract Refract. Surg. - 1988. - Vol. 14. - P. 173-179.

5. L'esperance F.A., Taylor D.M., Warner J.M. Human Excimer Laser Keratectomy: Short-Term Histopathology // J. Refract. Surg. - 1988. - Vol. 4. - N 4. - P. 118-124.

6. Лантух В.В., П̈ятин М.М., Искаков И.А., Ищенко В.Н., Кочубей С.А., Ражев А.М., Чеботаев В.П. Применение УФ эксимерных лазеров в микрохирургии глаза. - Новосибирск, I986. - I7 с. - (Препр./АН СССР.Сиб. отд-ние. Ин-т теплофизики; I5I-86).

7. Лебедева Л.И., Ахмаметьева Е.М., Салганик Р.И., Лантух В.В., Плтин М.М., Михайловская И.Е., Ищенко В.Н., Кочубей С.А., Рахев А.М., Рыданных О.В., Субботин В.М., Чеботаев В.П. Хромосомные мутации и регенерация тканей в роговицу глаза после УФ лазерного воздействия. -Новосибирск, I987. - 2 І с. - (Препр./АН СССР.Сиб.отд-ние Й-т теплофизики; I64-87).

8. Lantukh V.V., Pyatin M.M., Iskakov I.A., Ishchenko V.N., Kochubei S.A., Razhev F.M., Chebotayev V.P. UV Excimer Lasers in Eye Microsurgery // Lasers in the Life Sciences. - 1988. - Vol. 2. - N 4 . P. 313-326.

9. Pat. P 8902371 Spain. Device Correcting Ocular Refraction Anomalies / S.N. Fedorov, V.V.Lantukh, M.M.Pyatin, V.N. Ishchenko, S.A. Kochubei, A.M.Razhev, O.V.Rydannykh, A.V.Tsibizov, V.P.Chebotaev. (CCCP). 